(astma, prematuritet, hjertefeil, insulin, leukemi/cystisk fibrose), hvor den aktuelle behandlingen blir referert og diskutert..

Boken har en meget tiltalende layout, med som nevnt fine bilder, godt lesbar skrift, bokser med tekst ved siden av brødteksten, og egne sider med spørsmål og svar.

I de fem sykehistoriene, som jeg forstår er reelle, kommer vi svært nær innpå familiene, og spesielt hvordan det påvirker deres hverdag. Det er litt uvant for meg som liker kasuistikker til å illustrere faglige poenger, men som er vant med at de er anonymisert. Det fungerer imidlertid bra, og det er jo spennende og se hvordan familien har tilpasset seg den nye situasjonen med et sykt barn som får mange forskjellige medisiner.

Teksten ellers er lett å lese, og bør gi kunnskap både til målgruppen småbarnsforeldre, og også til oss i helsevesenet som arbeider med barn. Jeg fant mange gode pedagogiske poenger som jeg skal anvende i min egen praksis og i undervisning av kolleger, sykepleiere og studenter.

\section{Trond Flægstad}

Barneavdelingen

Universitetssykehuset Nord-Norge og

Universitetet i Tromsø

\section{Viktig om medisinsk ideologi mot krig og konflikter}

Arya N, Santa Barbara J, red.

Peace through health

How health professionals can work for a less violent world. 340 s. Sterling, VA: Kumarian

Press, 2008. Pris USD 40

ISBN 978-1-56549-258-5

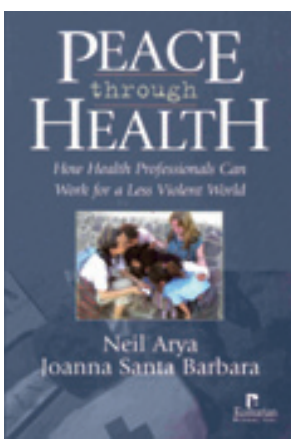

I det 20. århundre døde over 100 millioner mennesker som en direkte følge av krigshandlinger. WHO og Verdensbanken har anslått at krig vil være den åttende hyppigste årsak til død og uførhet i verden innen 2020.

I tillegg blir mange skadet fysisk og mentalt. Når krigen er utkjempet, etterlater den et samfunn med utarmet «sosial kapital». Intet ødelegger et lands infrastruktur så grundig som krig.

Dette er bakteppet for denne innholdsrike boken skrevet av 39 forfattere fra universiteter, fredsorganisasjoner og helseinstitusjoner over hele verden. De er alle eksperter på ulike sider av fredsarbeid og helse.
De gir en omfattende gjennomgang av alle aspekter av konfliktløsning og behandling av denne vår tids største helsetrussel, krig.

De to redaktørene er leger knyttet til McMaster-universitet i Canada, der «Fred og helse» er en sentral og viktig del av det medisinske universitetsmiljøet. Denne relativt nye gren av medisinen søker å mobilisere intelligens og ressurser i verdenssamfunnet med det mål å redusere muligheten for krig, dempe dens destruktive effekter og rehabilitere de samfunn som har vært utsatt for krigshandlinger

Henry Dunan var den første som brukte begrepet humanitcer hjelp under slaget ved Solferino i 1859. Han grunnla senere Røde Kors og inspirerte opprettelsen av Genèvekonvensjonen. Denne ble videreført i Menneskerettighetskonvensjonen av 1948. Det inspirerte helsepersonell til engasjement mot atomvåpen, klasebomber, landminer, napalm og stridsgass. En vesentlig del av dette engasjement dreier seg om innsiktsfull dokumentasjon av våpnenes grusomme potensial, og analyser av de mellommenneskelige mekanismer som ligger til grunn for konflikt og krig. De 27 artiklene gir grundig innsikt i denne samlede kunnskapsmengden. Her systematiseres dokumentasjon fra Leger mot atomvåpen, Leger for sosialt ansvar, og alle aspekter av det å legge medisinsk ideologi til grunn for kampen mot krig, tortur, utsultning og miljøødeleggelse.

Alle steder der tortur og dødsstraff utføres, er det medisinske medløpere, ofte stilletiende. Det sterkeste kapitlet i boken er skrevet av Wendy Orr. Etter å ha rapportert mishandling av fanger til ledelsen i det sørafrikanske fengslet der hun arbeidet som nyutdannet, uten å bli hørt, gjorde hun det ingen lege tidligere hadde gjort, hun la frem det hun har sett for The Supreme Court, 24.9.1984. Dette forandret hennes liv for alltid. Over natten ble hun i verdenspressen omtalt som henholdsvis helt og forræder, ble gjenstand for ros og fordømming, mottaker av blomster og drapstrusler. Hun ble fratatt muligheten til å arbeide. Hun spør seg senere hva som fikk henne, oppvokst $i$ en hvit middelklassefamilie i Sør-Afrika, til å gjøre dette «Jeg kan ikke si at min medisinske utdanning ved universitetet i Cape Town hadde særlig innflytelse på min beslutning - og det er en forferdelig anklage». Denne boken bør bli pensum ved våre medisinske fakulteter slik at ingen norsk lege i fremtiden kan komme med samme anklage.

\section{Mons Lie}

Kontor for internasjonalt samarbeid

Oslo universitetssykehus, Ullevål

\section{Kommunikasjonsteori i et sosiologisk perspektiv}

Helder J, Bredenlöw T, Nørgaard JL, red. Kommunikationsteori

En grundbog. 584 s, ill. København: Hans Reitzels Forlag, 2009. Pris DKK 525 ISBN 978-87-412-5126-4

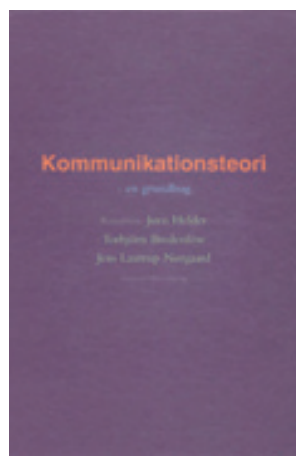

Denne boken springer ut fra en dansk universitetskonstruksjon Syddansk Universitet (SDU) - som tilbyr utdanning og forskning $i$ alle vanlige universitetsfag fordelt på seks geografisk spredte steder i søndre deler av Danmark.

I boken siteres en kilde på at det finnes mer enn 160 forskjellige definisjoner av kommunikasjon i sosiologisk litteratur. I forordet forteller redaktørene at bokens "grundlæggende intention er at fungere som en første indføring til et kolossalt stort og meget vanskelig afgrænseligt område. Bogen intenderer i overskuelig form at præsentere såvel de forskellige teoretiske som videnskabsteoretiske retninger i relation til kommunikation, ligesom en lang række centrale begreber præsenteres, defineres og diskuteres i bogen». Redaktørene opplyser at de ikke forventer at boken leses fra første til siste side, men at den skal fungere som et oppslagsverk.

De 20 frittstående kapitlene gruppert i fire hovedtemaer. Del 1 presenteres som «State-of-the-art» innen emneområdet kommunikasjon. Del 2 beskriver samfunnsvitenskapelige rammer for kommunikasjonsbegrepet. Del 3 tar for seg teorier om massekommunikasjon og del 4 inneholder betraktninger om språk og dets betydning for kommunikasjon.

Det gis korte innføringer i en rekke modeller for massekommunikasjon (Laswell, «Magic bullet», Shannon-Weaver, Maletzske, Katz og Lazarsfeldt, Roman Jakobson), og det gjøres en grundig drøfting av hermeneutikkens plass og grunnleggende filosofi som alternativ til naturvitenskapelig tenkning om kommunikasjon. Teorier for massekommunikasjon presenteres i et sosiologisk perspektiv på samfunnsnivå (Luhman, Habermas og Bourdieu). I kapittel 11-20 gis en bredere beskrivelse av hvordan kommunikasjonsteorier i dag anvendes i forskjellige virksomheter og sammenhenger. Den som leter etter teorier om kommunikasjon mellom enkeltmennesker vil lete forgjeves. Søren Kierkegaard finnes ikke blant referansene i denne boken.

Forlaget opplyser at boken kan «anvendes 
på forskellige uddannelser og i flere sammenhenger i et studium. Den er ikke specifikt bundet til noget fag eller nogen uddanelse.» Denne anmelder har vanskelig for å se at boken har noen plass i profesjonsutdanningene i helsefag, men noen kapitler kan kanskje være nyttig lesing for leger og annet helsepersonell som vil studere ledelse og vil vite mer om samfunnsvitenskapelige teorier omkring kommunikasjon.

\section{Tor Anvik}

Institutt for samfunnsmedisin

Universitetet i Tromsø

\section{Kjedelig lesning}

Andersson SI.

Hälsa och psykologi

248 s, tab, ill. Lund: Studentlitteratur, 2009

Pris SEK 286

ISBN 978-91-44-05619-7

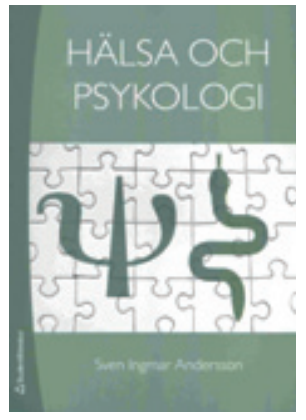

Forfatteren er knyttet til Lunds universitet som professor i psykologi med lang erfaring fra undervisning og forskning, bl.a. innen helsepsykologi. Boken er rettet mot studenter og profesjonelle innen psy-

kologi, sosialtjeneste og medisin. Den er bygd opp som en lærebok med omtale av modeller for helse og helseatferd, stress, livskvalitet, livsstil og til slutt et kapittel om helse og samfunn.

Jeg synes litt synd på svenske studenter som kanskje må lese denne boken som pensum, for den er kjedelig og støtter seg i stor grad på anbefalinger fra sosialstyrelsen eller WHO og er uten polemisk snert - og det på et felt som virkelig innbyr til ettertanke og kritikk.

Det man kunne forvente av en slik bok var i det minste et sammendrag av de store svingninger i hyppigheten av både hjerteog karsykdommer, kreft, ulykker og psykiske lidelser som har funnet sted de siste hundre år, og ev. hvilke psykososiale faktorer som har bidratt til denne utviklingen. Og hva med alternativ medisin som går som en farang over den vestlige verden? Ikke et ord om placeboeffekten.

Forfatteren henviser til en rekke avhandlinger og artikler, ikke minst fra amerikansk psykologi. Men det står ingenting om nordiske undersøkelser som har dokumentert betydningen av sosialt nettverk både for sykdomsutvikling og prognose.

Saksregistret er svakt uten henvisning til verken alkohol, alderdom, demens, fibro- myalgi, suicid eller en rekke andre temaer man ville vente å finne i en slik bok.

\section{Einar Kringlen}

Psykiatrisk institutt

Universitetet i Oslo

\section{Helsepsykologi for psykologer}

Espnes GA, Smedslund G. Helsepsykologi

445 s, tab, ill. 2. utg. Oslo: Gyldendal Akademisk, 2009. Pris NOK 445

ISBN 978-82-05-39075-1

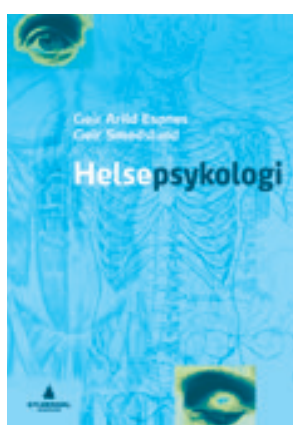

Forfatterne av denne læreboken er psykologer. Geir Arild Espnes er professor i helsevitenskap ved Institutt for sosialt arbeid og helsevitenskap, Norges teknisk-naturvitenskapelige universitet, mens Geir

Smedslund er seniorforsker ved Nasjonalt kunnskapssenter for helsetjenesten. Første utgave av boken kom i 2001.

For forfatterne dreier helsepsykologi seg om hvordan «følelser, psykiske tilstander eller ulik atferd påvirker vår helsetilstand», og de slutter seg til Matarazzos definisjon fra 1980 der helsepsykologi kan sies å være de samlede bidrag psykologien gir for å forstå helse og velvære. Dette er et felt som psykiatrien og sosialmedisinen tidligere har hatt et slags monopol på, men nå forsøker åpenbart psykologene å overta.

I tråd med tidens motebølger er teksten nå ifølge forfatterne «vridd i positiv retning, mot positiv psykologi og positiv helsepsykologi». De ønsker å konsentrere seg mer om løsningsalternativer enn problemer og risiko.

Stoffet presenteres i fire hoveddeler: Del 1 tar for seg historikk og forskningsmetoder; Del 2 helse og sykdom, der stress og mestring, personlighetsfaktorer og kroniske sykdommer står sentralt; Del 3 helse og livsstil, der kosthold, fysisk aktivitet og rusmidler blir omtalt; og til slutt Del 4 om å holde seg frisk, der forebygging er viktig.

Forfatterne unngår å ta opp kontroversielle spørsmål, og er i stor grad refererende. Hvorfor kunne man f.eks. tidligere påvise en sammenheng mellom A-væremåte og hjerteinfarkt, men sjeldnere i dagens studier? Hva var årsaken til økningen av hjerteinfarkt $i$ de vestlige land etter siste verdenskrig, og hva skyldtes nedgangen som fulgte noen år senere? Disse store endringene må tilskrives miljøfaktorer og ikke genetiske forhold. Man skulle da tro at psykologer hadde noe å si her. Heller ikke har forfatterne synspunkter på de nye epidemier av depresjon, fibromyalgi, nakkeslengskader og kronisk utmattelsessyndrom («ME») som mediene og pasienter er så opptatt av.

Det refereres en del til internasjonal litteratur, vesentlig fra WHO. Norske og andre skandinaviske undersøkelser diskuteres praktisk talt ikke - hvis det da ikke gjelder studier utført av psykologer. Stikkordregisteret er tynt og virker lite brukervennlig med relativt få litteraturreferanser fra de siste ti år.

Denne boken er bedre enn den svenske Hälsa och psykologi av Svenn Ingmar Andersson (1), men det er også her lite å hente for leger og helsepersonell. Flere kapitler er lite informative og til dels misvisende. Årsaken er nok at forfatterne verken er leger eller medisinske epidemiologer.

Einar Kringlen

Psykiatrisk institutt

Universitetet i Oslo

Litteratur

1. Andersson SI. Hälsa och psykologi. Lund: Studentlitteratur, 2009

\section{Kort og godt om søvnløshet}

Wolland AM, Heier MS

Søvnløshet

88 s, ill. Oslo: Cappelen Akademisk Forlag.

2009. Pris NOK 248

ISBN 978-82-02-306168

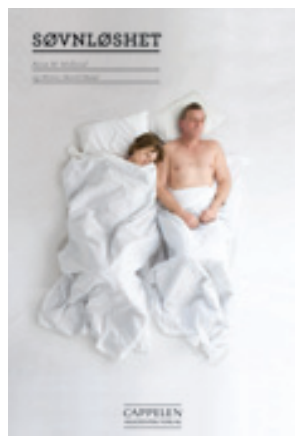

Forfatterne er to nestorer i det norske søvnmedisinske miljøet. Mange vil ha kjennskap til deres to andre bøker om søvnsykdommer på norsk: Søvn og søvnforstyrrelser (2005) og den nylig utgitte Barn og søvn (2009) $(1,2)$.

Forfatterne fortsetter i Søvnløshet sin gjennomgang av sentrale søvntemaer. Boken er relativt kortfattet og gir en lett tilgjengelig gjennomgang av de viktigste temaene om søvnløshet. Den inneholder praktiske råd og veiledninger som er lett omsettelige til den kliniske hverdag.

Boken vil være nyttig for alle leger og annet heldepersonell som kommer i kontakt med denne type problemstillinger. Språket er såpass enkelt og lite fagmedisinsk at også folk som ikke er fagpersoner vil forstå det aller meste og ha utbytte av innholdet.

De fleste som jobber klinisk vil i sin 